\title{
Роль нематериальных активов в создании ценности компании: теоретические и практические аспекты
}

\author{
Гаранина T.A. ${ }^{12}$
}

\begin{abstract}
Настоямая работа посвящена вопросам оченивания $u$ выявления роли нематериальных активов в процессе увеличения иенности компании. В первой части представлен ряд моделей, позволяющих наглядно выявить и определить роль данного вида активов в создании иенности компании. Вторая часть исследования носит практический характер. На основе модели остаточной операчионной прибыли (REOI - residual operating incoте) в работе предложен подход к оценке трех видов иенностей нематериальных активов: фундаментальной, рыночной и теоретической. Оченивание проводилось для выборки российских компаний, акции которых торгуются на РТС за период с 2001-го по 2006 г. Полученные результаты позволили выделить те компании, которые являются недоочененными с точки зрения имеющихся у них нематериальных активов.
\end{abstract}

JEL: L20, M41, M10

Ключевые слова: нематериальные активы, интеллектуальный капитал, фундаментальная цеенность, ценностно-ориентированный менеджмент

\section{Введение}

Традиционно наиболее важными ресурсами компании считались ее материальные активы, особенно физические активы и капитал. Именно они лежали в основе достижения ею устойчивых конкурентных преимуществ и создании ценности. Безусловно, эти ресурсы и до сих пор играют существенную роль в конкурентоспособности компаний. Тем не менее в последнее десятилетие в условиях динамической и постоянно меняющейся среды для получения превосходства над конкурентами компаниям необходимо акцентировать свое внимание на имеющихся у них нематериальных активах [Grant, 1991; Nahapiet, Ghoshal, 1998; Teece, 2000].

Организация имеет возможность достигать высоких результатов на рынке и создавать ценность для акционеров в случае, если применяются стратегии, которые отвечают возможностям рынка и позволяют максимально эффективно использовать имеющиеся внутренние ресурсы и способности. Согласно проведенным исследованиям технологические изменения и переход к экономике знаний изменил отношения инвесторов к оценке ценности. Будущие финансовые результаты чаще гораздо лучше предсказываются нефинансовыми индикаторами, чем финансовыми. В силу этого финансовым менеджерам и инвесторам необходимо более четко понимать состав и структуру нематериальных активов, а также их влияние на создание ценности компании.

В работе Каплан и Нортон [Kaplan, Norton, 2005, с. 15] сказано, что «нематериальные активы - это основной источник устойчивого создания стоимости». Исследование [Lev, Feng, 2001] говорит о том, что 40\% рыночной стоимости компании не отражено в балансе, при этом для компаний из высокотехнологичных отраслей эта цифра достигает $50 \%$. Таким образом, до 50\% ценности компании может приходиться на нематериальные активы, а по результатам исследований других авторов эта цифра может составлять 90\%. В другой работе [Лев, 2003] не раз подчеркивается мысль о том, что нематериальные активы являются «главными драйверами роста и ценности компаний в большинстве секторов экономики».

12 Канд. эконом. наук, ассистент кафедры финансов и учета Высшей школы менеджмента СанктПетербургского государственного университета.

Выпуск \#4(12), 2009

() Электронный журнал Корпоративные Финансы, 2009 


\section{1. Теоретические модели влияния НМА на ценность компании}

\section{1. Модель «миксер создания ценности»}

Существуют различные модели, графически иллюстрирующие место и роль НМА в создании ценности компаний. Одной из наиболее часто упоминаемых в научных исследованиях является модель создания ценности компании, предложенная в отчете PRISM $^{13}$. Данный проект сфокусирован на компетенциях, возможностях и потоках знаний, как основе развития современной организации.

Данная модель носит название «миксер создания ценности» [PRISM, 2003] (рис. 1).

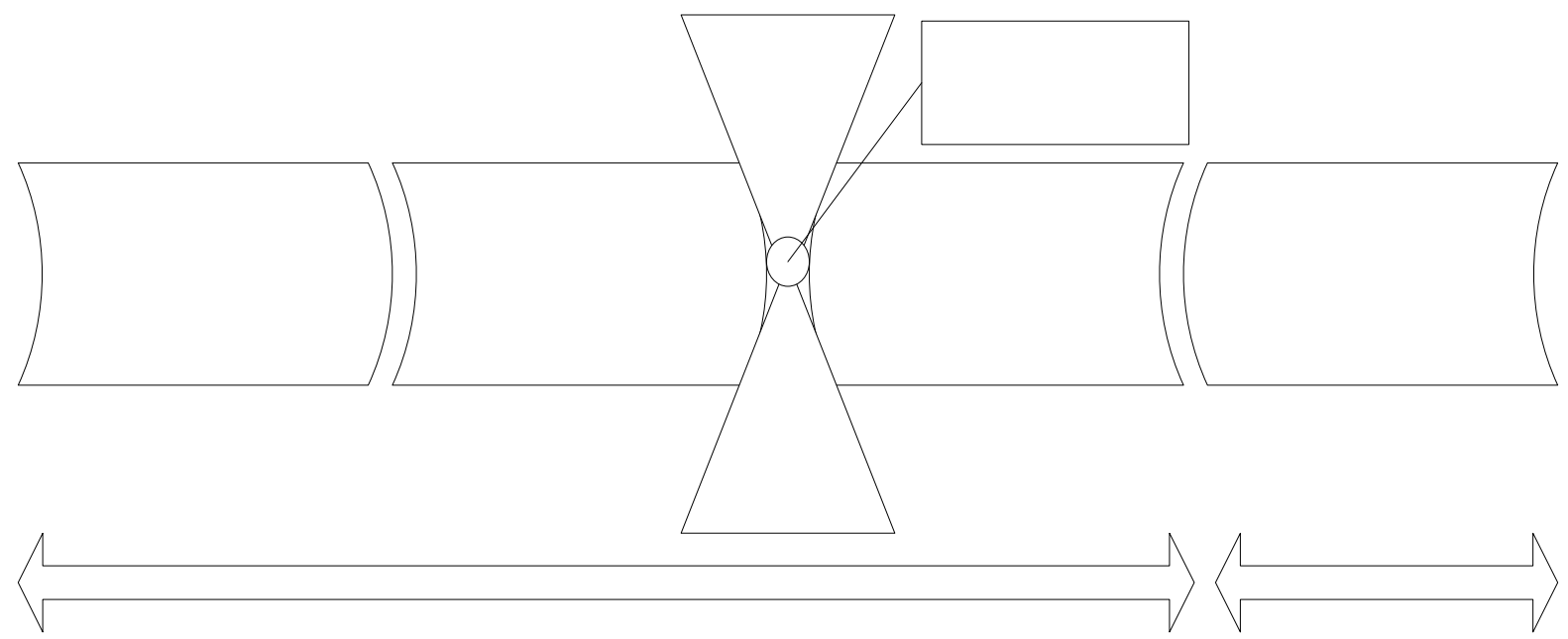

Рис. 1. Миксер создания ценности

Источник: [PRISM, с. 37].

Bсе четыре блока активов относятся к стратегическим активам организации. Это активы, которые организация может использовать прямо сейчас. Слева от миксера создания ценности находятся активы, на которые организация имеет те или иные права, и эти права являются законодательно оформленными. К материальным активам относятся физические активы - такие, как земля, завод, машины и оборудование, деньги и денежные эквиваленты, ценные бумаги и инвестиции. Нематериальные активы, в свою очередь, включают в себя объекты интеллектуальной собственности, бренды, торговые марки, ноухау и т.д.

Справа от «миксера создания ценности» расположены нематериальные компетенции и латентные способности, последние названы разработчиками модели «активами в ожидании», на которые у компании нет официальных прав собственности. К нематериальным компетенциям относятся организационный и человеческий капитал. Под латентными способностями подразумевается лидерство, талант в работе, организационные способности, включающие в себя также сети, рыночные возможности и инновационные способности. Данные способности необходимы в непредсказуемой, динамично изменяющейся среде, и реальная потребность в них ощущается тогда, когда компания сталкивается с необходимостью перестраивать свою текущую деятельность для того, чтобы соответствовать новым условиям.

В центре модели находится «миксер создания ценности», в котором менеджер может

\footnotetext{
${ }^{13}$ Eustace C. (ed.). PRISM (Policy making, reporting and measuring, intangibles, skill development, management) междисциплинарный европейский проект, созданный для того, чтобы более глубоко понять природу и вопросы оценки и управления, связанные с нематериальными активами в современной экономике. www.euintangibles.net.
} 
использовать и управлять всеми имеющимися в его распоряжении ресурсами для того, чтобы максимизировать ценность фирмы.

Разработчики модели акцентируют внимание на том, что в сегодняшней экономике с очень высоким уровнем конкуренции организации должны иметь доступ к уникальным ресурсам или, по крайней мере, трудно имитируемым ресурсам и компетенциям, которые позволяют получить устойчивые конкурентные преимущества. Именно эффективное управление нематериальными ресурсами является ключом к превосходству над конкурентами.

\section{2. Модель «нематериальная цепочка ценности»}

В работе Ахонен [Ahonen, 2000] представлена «нематериальная цепочка ценности» (рис. 2), в результате которой фирма может получить доходность, превышающую среднеотраслевую.

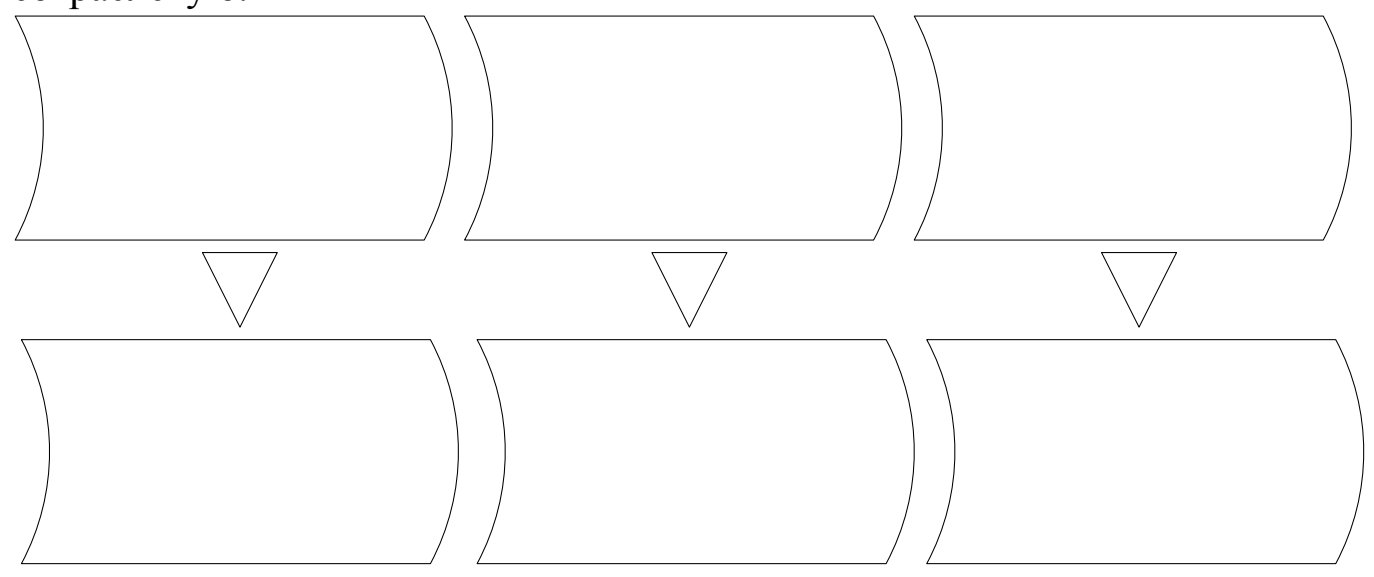

Рис. 2. Нематериальная цепочка ценности

Получение превосходства над конкурентами в виде позитивной добавленной рыночной стоимости (market value added - MVA) возможно лишь благодаря использованию нематериальных активов, которые способствуют тому, что компания может стать обладателем:

- эффективного производства (экономия на затратах и на разнообразии, превосходство в технологии, TQM, эффективные контракты с поставщиками);

- $\quad$ зарегистрированных прав собственности (патенты, бренды, права собственности);

- повышающегося спроса (растущие рынки);

- высокоэффективного менеджмента.

Коммерционализированные НМА компания может получить благодаря либо сделкам по слияниям и поглощениям, либо собственным усилиям по их генерированию.

Классифицировать нематериальные активы, которые лежат в основе процесса генерирования, можно следующим образом (табл. 2): 
Таблица 2

Генерирующие НМА

\begin{tabular}{|l|l|l|}
\hline \multicolumn{1}{|c|}{$\begin{array}{c}\text { Генерирующие } \\
\text { НМА }\end{array}$} & \multicolumn{1}{|c|}{\begin{tabular}{c}
\multicolumn{1}{|c|}{ Финансовые } \\
индкаторы
\end{tabular}} & Нефинансовые индикаторы \\
\hline Человеческий & - Затраты на & - Количество сотрудников \\
образование и развитие & - Возрастная структура \\
& - Затраты на выплату & - Уровень образования \\
& 3/пл & - Уровень зарплаты \\
& - Затраты на найм & \\
\hline Внутренняя & - Затраты на & - Текучесть персонала \\
структура & информационные & - Количество \\
& технологии & компьютеров/кол-во \\
& - Затраты на социальную & сотрудников \\
& ответственность & - Постоянный/временный \\
& - Затраты на ТQМ & персонал \\
\hline Внешняя структура & - Затраты на маркетинг & - База клиентов \\
& - Затраты на & - База поставщиков \\
& поддержание отношений & - Уровень \\
& - Сетевые затраты & удовлетворенности клиентов \\
& \multicolumn{2}{|l}{ Рейтинг работодателей } \\
\hline
\end{tabular}

Из представленного подхода к созданию ценности можно сделать вывод о том, что в основе получения компанией устойчивых конкурентных преимуществ лежит коммерциализация нематериальных активов, т.е. активов, которые могут приносить компании прибыль.

Вот почему для увеличения ценности компании менеджерам необходимо обращать внимание и эффективно управлять бизнес-процессами и стратегически важными ресурсами, к которым и относятся нематериальные активы.

\section{3. Взаимосвязь составляющих нематериальных активов и ценности компании}

Выше были представлены лишь несколько моделей, характеризующих роль нематериальных активов в создании ценности. Они являются управленческим инструментом, который позволяет создать картину имеющихся у компании ресурсов.

Автор данной работы предлагает следующий подход к выявлению роли нематериальных активов и их составляющих в создании ценности компании (рис.3): 


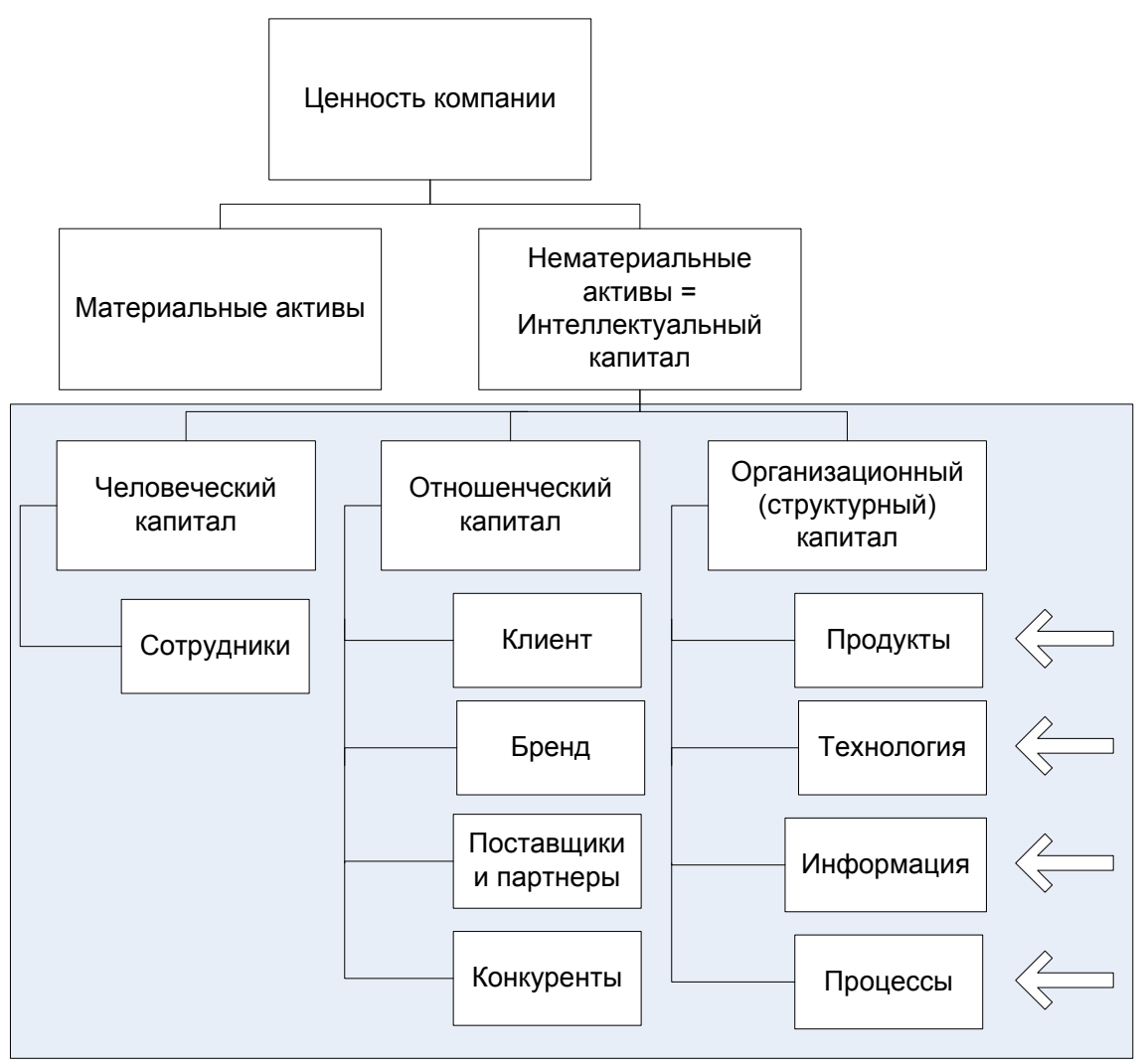

Рис. 3. Влияние составляющих НМА на ценности компании

В связи с тем, что все чаще именно нематериальные активы рассматриваются авторами в качестве основного источника создания ценности компании, для менеджеров, безусловно, важно рассматривать не только отдельные типы, но и отдельные элементы НМА в качестве факторов создания ценности. Так, можно выделить 9 факторов создания ценности (табл. 3).

Таблица 3

Факторы создания ценности

\begin{tabular}{|c|c|}
\hline Фактор & Определение \\
\hline Сотрудники & $\begin{array}{l}\text { Экономическая ценность, которую } \\
\text { компания получает от работы своих } \\
\text { сотрудников (их знаний и умений) }\end{array}$ \\
\hline Продукты и услуги & $\begin{array}{lll}\text { Экономическая ценность, } & \text { которую } \\
\text { получает компания от продуктов и услуг, } \\
\text { которые она предлагает рынку, понимая } \\
\text { потребности и ожидания клиентов }\end{array}$ \\
\hline Информация & $\begin{array}{l}\text { Экономическая ценность, } \\
\text { получает которую } \\
\text { аккумулировать компания от информацию умения } \\
\text { использовать ее в нужном месте и в нужное } \\
\text { время }\end{array}$ \\
\hline Технология & $\begin{array}{l}\text { Экономическая ценность, которую } \\
\text { получает компания от используемой } \\
\text { технологии, являющейся основой работы } \\
\text { всей организации }\end{array}$ \\
\hline Процессы & $\begin{array}{l}\text { Экономическая } \\
\text { полунность, }\end{array}$ \\
\hline
\end{tabular}




\begin{tabular}{|l|l|}
\hline Клиент & $\begin{array}{l}\text { Экономическая ценность, которую } \\
\text { получает компания благодаря лояльности } \\
\text { потребителей своих товаров и услуг }\end{array}$ \\
\hline Бренд & $\begin{array}{l}\text { Экономическая ценность, которую } \\
\text { компания получает от наличия известного и } \\
\text { узнаваемого бренда }\end{array}$ \\
\hline Поставщики и партнеры & $\begin{array}{l}\text { Экономическая ценность, которую } \\
\text { компания получает от своего положения на } \\
\text { рынке (репутация, бренд, доля рынка) }\end{array}$ \\
\hline $\begin{array}{l}\text { Экономическая ценность, которую } \\
\text { получает организация от установленных } \\
\text { альянсов и ассоциаций (финансовых, } \\
\text { стратегических и др.) с внешними } \\
\text { организациями и от налаженных связей с } \\
\text { поставщиками }\end{array}$ \\
\hline
\end{tabular}

Объективно важным является то, что нематериальные активы очень тесно взаимосвязаны с материальными активами (например, технологии и знания, реализованные в произведенном самолете) и в труде (знания сотрудников), что говорит об их близкой связи и в создании ценности компании. Поэтому вопрос трансформации нематериальных активов в материальные ценности является на сегодняшний день очень актуальным для большинства компаний. Все вышесказанное еще раз подтверждает тот факт, что менеджерам необходимо более точно понимать, каким образом стоит управлять активами, а в особенности нематериальными активами для создания ценности компании и поддержания ее устойчивых конкурентных преимуществ.

\section{2. Разработка моделей оценивания нематериальных активов}

Для эмпирического подтверждения роли нематериальных активов в создании ценности компании чрезвычайно сложным и дискуссионным является вопрос их оценивания. Сложность проблемы связана не только со спецификой предмета оценки (его нематериальность), но и с тем, что в данном случае те или иные модели оценивания фактически дают не только численную оценку предмета оценивания, но и определенным образом определяют его сущность.

В данной работе предложен метод оценивания нематериальных активов на основе модели остаточной операционной прибыли (residual operating income - REOI) как варианта модели фундаментальной ценности собственного капитала. Как сказано в работе Волокова и Гараниной [Волков, Гаранина, 2007] теоретические разработки, практическое применение модели остаточной операционной прибыли, обзор фундаментальных работ и современных публикаций представлены в трудах Волкова, Бухвалова и Березинец [Волков, 2006, 2005а, 2005б, 2004a; 2004б; Бухвалов, Волков, 2005а, 2005б; Волков, Березинец, 2006а, 2006б].

В общем виде модель остаточной операционной прибыли (residual operating income REOI) может быть представлена следующим образом:

$$
V_{E}^{R E O I_{j}}=E_{0}^{B V}+\sum_{j=1}^{\infty} \frac{R E O I_{j}}{\left(1+k_{W}\right)^{j}}=\left[N A_{0}^{B V}+\sum_{j=1}^{\infty} \frac{R E O I_{j}}{\left(1+k_{W}\right)^{j}}\right]-D_{0},
$$

где $V_{E}^{R E O I}-$ фундаментальная ценность собственного капитала по модели остаточной операционной прибыли;

$E_{0}^{B V}, N A_{0}^{B V}, D_{0}$ - балансовая стоимость на момент оценивания собственного капитала, чистых активов и долга соответственно;

$R E O I_{j}$ - остаточная операционная прибыль в ј-ом г. Вариантом показателя REOI 
является $E V A$ (добавленная экономическая стоимость);

$k_{W}$ - средневзвешенные затраты на капитал ( $\left.W A C C\right)$

При этом остаточная операционная прибыль равна чистой операционной прибыли за вычетом затрат на инвестированный капитал:

$$
R E O I_{j}=N O P A T_{j}-k_{W} \times N A_{j-1}^{B V}
$$

где NOPAT - чистая операционная прибыль (net operating profit after taxes).

Хотелось бы обратить особое внимание на то, как автор понимает термин «чистые активы» (NA), который в литературе используется по-разному. Под чистыми активами может, в частности, пониматься собственный капитал организации [О порядке оценки... 1996], как разница между всеми активами и всеми обязательствами организации (платными и бесплатными). В то же время в западной и западно ориентированной литературе по финансовому менеджменту чистые активы понимаются в ином смысле, а именно как активы, финансируемые за счет платных источников. Или с точки зрения основного балансового равенства - как активы организации за вычетом краткосрочных бесплатных обязательств, связанных с основной (текущей) деятельностью организации [Copeland et al., 1995; Knight, 1998; Higgins, 1995]. Именно в этом смысле мы и будем далее определять указанное понятие. Таким образом, в формулах (1) и (2) и далее в работе чистые активы (net assets - NA) организации определяются как разница между всеми активами (total assets TA) и бесплатными обязательствами (кредиторской задолженностью — accounts payable AP).

В работе Волкова и Гараниной [Волков, Гаранина, 2007] представлены преобразования, которые необходимы для получения фундаментальной оценки материальных и нематериальных активов с использованием модели остаточной операционной прибыли.

Допущение 1. Компании, принадлежащие к одной отрасли, характеризуются приблизительно одинаковой структурой активов. При этом можно предположить, что одна денежная единица, вложенная в материальные активы, должна давать по всем компаниям отрасли одинаковую отдачу.

Допущение 2. Внутриотраслевые различия в доходности компаний объясняются исключительно уникальными нематериальными активами каждой из них.

Данные допущения также были использованы и в исследованиях, проводимых на зарубежных рынках капитала, например в работах Эйбоди и Баруха, Фримана и Соит, Грилишес, Холл [Aboody, Baruch, 2001; Freeman, Soete, 1997; Griliches, 1995; Hall, 1993].

Если принять указанные допущения, то это означает, что:

- доходность, которую дают материальные активы, одинакова по всем компаниям отрасли и равна среднеотраслевой доходности;

- доходность, которую дают нематериальные активы, - это разница между фактической доходностью компании и среднеотраслевой доходностью. В этом смысле эффекты влияния нематериальных активов на общую доходность могут быть как положительными (в случае превышения доходности компании над среднеотраслевой), так и отрицательными (в противном случае).

Формула фундаментальной ценности активов с учетом преобразований может быть представлена как:

$$
V_{A}^{R E O I}=N A_{T}^{B V}+\frac{R E O I}{k_{W}}=\left[N A_{T}^{B V}+\frac{R E O I_{T}}{k_{W}}\right]+\left[\frac{R E O I_{I}}{k_{W}}\right]=V_{T}+V_{I},
$$

где фундаментальная ценность активов компании раскладывается на фундаментальную ценность материальных $\left(V_{T}\right)$ и нематериальных активов $\left(V_{I}\right)$ следующим образом: 


$$
\begin{aligned}
& V_{T}^{R E O I}=N A_{T}^{B V}+\frac{N A_{T}^{B V} \times\left(R O N A_{I A V G}-k_{W}\right)}{k_{W}}= \\
& =N A_{T}^{B V} \times\left(1+\frac{R O N A_{I A V G}-k_{W}}{k_{W}}\right)=N A_{T}^{B V} \times \frac{R O N A_{I A V G}}{k_{W}}, \\
& V_{I}^{R E O I}=\frac{R E O I_{I}}{k_{W}}=N A_{T}^{B V} \times \frac{R O N A-R O N A_{I A V G}}{k_{W}} .
\end{aligned}
$$

Из высказанных выше предположений можно сделать два принципиальных вывода:

- фундаментальная ценность материальных активов компании может быть либо положительной, либо нулевой (в случае, если среднеотраслевая доходность больше или равна нулю);

- фундаментальная ценность нематериальных активов может быть при неотрицательном значении среднеотраслевой доходности как положительной, так и отрицательной.

В представленной данной работе анализируется не только фундаментальная ценность (fundamental value) нематериальных активов. Кроме данного вида оценки также рассматриваются рыночная ценность (market value), т.е. ценность актива, по которой осуществляются сделки на рынке, и теоретическая, т.е. ценность, рассчитанная согласно разработанной эконометрической модели.

Как показали данные по анализируемой выборке компаний, балансовая стоимость (book value) HMA, т.е. стоимость активов организации, по которой они отражены в финансовой отчетности организации, в большинстве российских компаний либо слишком мала, либо в принципе равна нулю.

В целом рыночную ценность всех активов компании можно описать следующей зависимостью:

$$
P_{A}^{M}=P_{E}^{M}+P_{D}^{M}
$$

где $P_{A}^{M}, P_{E}^{M}, P_{D}^{M}$ - рыночная ценность активов, собственного капитала и долга соответственно.

Учитывая то, что рыночная ценность собственного капитала есть рыночная капитализация (Cap), а рыночная ценность долга обычно предполагается равной его балансовой стоимости $(D)$, уравнение $(7)$ может быть переписано в виде:

$$
P_{A}^{M}=C a p+D \text {. }
$$

Рыночная ценность активов для расчета модели определяется, как средневзвешенное по объемам торгов значение рыночной капитализации за II квартал года, следующего за отчетным ${ }^{14}$, плюс балансовая стоимость долга на конец отчетного периода.

Таким образом, можно сформулировать однофакторную модель, в которой показывается влияние на рыночную ценность активов исключительно фундаментальной ценности нематериальных активов $\left(V_{I}\right)$, определяемой в соответствии с выражением (6), следующим образом:

$$
P_{A}^{M}=\lambda_{0}+\lambda_{1} \times V_{I}+\varepsilon_{1}
$$

\footnotetext{
${ }^{14}$ Обоснование такого порядка расчета рыночной капитализации приведено, в частности, в: [Волков, 2006б; Волков, Березинец, 2006а, 2006б].
} 
где $\lambda_{0}, \lambda_{1}$ - параметры уравнения регрессии;

$\varepsilon_{1}$ - случайный член.

Модель, которая позволяет оценить влияние на рыночную ценность активов только фундаментальной ценности материальных активов $\left(V_{T}\right)$, определяемой в соответствии с (5), можно представить в виде:

$$
P_{A}^{M}=\beta_{0}+\beta_{1} \times V_{T}+\varepsilon_{2}
$$

где $\beta_{0}, \beta_{1}$ - параметры уравнения регрессии;

$\varepsilon_{2}$ - случайный член.

В силу вышесказанного рыночную ценность НМА $\left(P_{I}^{M}\right)$ можно представить следующим образом:

$$
P_{I}^{M}=C a p+D-\mathbb{E}_{T}^{M},
$$

где Сар — рыночная капитализация компании;

$D$ - долг;

$f_{T}^{M}$ - рыночная ценность материальных активов.

При этом рыночная ценность материальных активов $\left({ }_{T}^{f^{M}}\right)$ вычисляется, исходя из (10) через фундаментальную ценность данного вида активов $\left(V_{T}\right)$ :

$$
\AA_{T}^{M}=\beta_{0}+\beta_{1} * V_{T},
$$

где $\beta_{0}, \beta_{1}$

— оцененные параметры уравнения регрессии (табл. 4).

\begin{tabular}{|c|c|c|c|c|c|c|}
\hline $\begin{array}{c}\text { Период } \\
\text { наблюдения }\end{array}$ & 2001 & 2002 & 2003 & 2004 & 2005 & 2006 \\
\hline $\begin{array}{l}\text { Оцененный } \\
\text { параметр } \\
\left(\mathscr{\beta}_{0}\right)\end{array}$ & 3613,14 & 3457,30 & 4289,88 & 4603,02 & 11289,25 & 9290,69 \\
\hline $\begin{array}{l}\text { Оцененный } \\
\text { параметр } \\
\left(\mathscr{\beta}_{1}\right)\end{array}$ & 0,718 & 1,009 & 0,904 & 1,052 & 0,795 & 1,010 \\
\hline
\end{tabular}

Таблица 4

Значения оцененных параметров уравнения (12) для всей выборки компаний

Для расчета теоретической ценности НМА $\left(P_{I}^{T}\right)$ необходимо вычислить значения параметров следующего уравнения регрессии:

$$
P_{I}^{M}=\gamma_{0}+\gamma_{1} * V_{I}+\varepsilon_{3}
$$

где $\gamma_{0}, \gamma_{1}$ - параметры уравнения регрессии;

$\varepsilon_{3}$ - случайный член.

Зная это, теоретическая ценность НМА рассчитывается следующим образом:

$$
P_{I}^{T}=\notin_{0}+f_{1} * V_{I}
$$

где $\ell_{0}, f_{1}$ - оцененные параметры уравнения регрессии (табл.5) 
Таблица 5

Значения оцененных параметров уравнения (14) для всей выборки компаний

\begin{tabular}{|l|c|c|c|c|c|c|}
\hline $\begin{array}{c}\text { Период } \\
\text { наблюдения }\end{array}$ & $\mathbf{2 0 0 1}$ & $\mathbf{2 0 0 2}$ & $\mathbf{2 0 0 3}$ & $\mathbf{2 0 0 4}$ & $\mathbf{2 0 0 5}$ & $\mathbf{2 0 0 6}$ \\
\hline $\begin{array}{l}\text { Оцененный } \\
\text { параметр } \\
\left(\begin{array}{l}\left.\mathbb{F}_{0},\right)\end{array}\right.\end{array}$ & 1409,53 & 1260,21 & 2677,27 & 1124,52 & 1057,43 & 1705,31 \\
\hline $\begin{array}{l}\text { Оцененный } \\
\text { параметр } \\
\left(\mathbb{f}_{1}\right)\end{array}$ & 0,263 & 0,006 & $-0,059$ & 0,149 & 0,496 & 0,149 \\
\hline
\end{tabular}

\section{3. Статистические данные}

Оценивание ценности нематериальных активов проводилось для выборки российских компаний-эмитентов, акции которых торгуются на фондовой бирже РТС. В выборку не были включены финансовые посредники (банки и финансовые институты) с целью соблюдения однородности данных. Окончательный объем выборки составили 43 компании. В выборку вошли компании шести агрегированных отраслей: машиностроение (включает в себя авиационную промышленность и автомобилестроение), добывающая промышленность (включает в себя нефтегазовые холдинги и нефтегазодобывающую промышленность), энергетика, связь, химическая промышленность, металлургия (черная и цветная).

Для проведения исследования использовались данные общедоступной неконсолидированной финансовой отчетности компаний за 2001-2006 гг., представленные на их сайтах. Общий объем выборки составил 258 фирм-лет (43 компании за 6 лет).

Первичная информация о рыночной капитализации исследуемых компаний получена с сайта фондовой биржи РТC (www.rts.ru). При анализе использовалось средневзвешенное значение капитализации за II квартал. В силу того что для всех расчетов валютой избран рубль, рыночная капитализация по данным РТС была пересчитана в рубли по среднему курсу.

Одним из основных вопросов при проведении анализа, как уже упоминалось выше, является проблема определения величины средневзвешенных затрат на капитал $\left(\mathrm{k}_{\mathrm{W}}\right)$. B данном исследовании в качестве величины $\mathrm{k}_{\mathrm{W}}$ принимается среднее значение RONA для каждой отрасли.

Общие статистические характеристики анализируемой выборки за 2001-2006 гг. представлены в табл. 6.

Таблица 6

Общие статистические характеристики анализируемой выборки

\begin{tabular}{|c|c|c|c|c|}
\hline № & Наименование показателя & Среднее & Медиана & $\begin{array}{c}\text { Стандартное } \\
\text { отклонение }\end{array}$ \\
\hline 1 & $\begin{array}{l}\text { Рыночная стоимость } \\
\text { активов (млн руб.) }\end{array}$ & 103244 & 24864 & 16130 \\
\hline 2 & Рыночная стоимость акций & 0,000259 & 0,0000192 & 0,00077 \\
\hline 3 & $\begin{array}{l}\text { Фундаментальная ценность } \\
\text { материальных активов (млн } \\
\text { руб.) }\end{array}$ & 77193 & 22792 & 11753 \\
\hline 4 & $\begin{array}{l}\text { Фундаментальная ценность } \\
\text { нематериальных } \\
\text { (млн руб.) }\end{array}$ & 2374 & -925 & 7044 \\
\hline
\end{tabular}




\section{4. Расчет трех видов ценностей нематериальных активов российских компаний}

Для выборки российских компаний автором рассчитаны три вида ценностей нематериальных активов: фундаментальная, рыночная и теоретическая, сравнение которых позволило сделать ряд выводов.

При более детальном рассмотрении ценностей можно выделить две группы компаний те, у которых фундаментальная ценность нематериальных активов выше их рыночной, и наоборот. Данный анализ позволяет сделать вывод об оценке компании внешними инвесторами - в случае, если фундаментальная ценность превышает рыночную, это означает, что компания недооценена с точки зрения ее нематериальных активов, и наоборот.

Как было отмечено выше, фундаментальная ценность нематериальных активов может быть как положительной, так и отрицательной (в случае если менеджмент компании неэффективно управляет НMA, что не позволяет компании получить доходность выше среднеотраслевой). Рыночная ценность уникальных активов компании может быть как положительной, так и нулевой (в случае если их ценность равна нулю в общей ценности активов компании).

Переоцененные компании с точки зрения данного подхода представлены в табл. 7.

Переоцененные компании (в млн руб.) в 2006 г.

Таблица 7

\begin{tabular}{|l|l|c|c|c|}
\hline \multirow{2}{*}{ o. Компания } & $\begin{array}{c}\text { Рыночная } \\
\text { ценность НМА }\end{array}$ & $\begin{array}{c}\text { Фундаментальная } \\
\text { ценность НМА }\end{array}$ & Разница \\
\hline 1 & Лукойл & 174954,75 & 4568,06 & 170386,69 \\
\hline 2 & Сибнефть & 295615,36 & 102094,09 & 193521,27 \\
\hline 3 & Норильский никель & 16980,14 & $-88780,01$ & 105760,15 \\
\hline 4 & Мосэнерго & 39901,98 & $-63322,73$ & 103224,71 \\
\hline 5 & Сургутнефтегаз & 3367,57 & $-33394,32$ & 36761,89 \\
\hline 6 & КамАЗ & 17502,54 & $-13213,08$ & 30715,62 \\
\hline 7 & ЦентрТелеком & 9393,17 & $-15762,91$ & 25156,08 \\
\hline 8 & Кузбасэнерго & 2849,21 & $-10816,13$ & 13665,34 \\
\hline 9 & РАО ЕЭС & 41031,36 & 23229,21 & 17802,15 \\
\hline 10 & Уралсвязьинформ & 3804,02 & $-5445,00$ & 9249,02 \\
\hline 11 & ВСМПО-АВИСМА & 7781,61 & 143,68 & 7637,93 \\
\hline 12 & Уралкалий & 6763,20 & $-573,13$ & 7336,33 \\
\hline 13 & ГАЗ & 5381,73 & 1598,67 & 3783,07 \\
\hline 14 & Московская ГТС & 3422,72 & 337,95 & 3084,77 \\
\hline
\end{tabular}

Компании, у которых фундаментальная ценность НМА превышает их рыночную ценность, представлены в табл. 8. 
Недооцененные компании (в млн руб.) в 2006 г.

\begin{tabular}{|l|l|c|c|c|}
\hline № & \multicolumn{1}{|c|}{ Компания } & $\begin{array}{c}\text { Фундаментальная } \\
\text { ценность НМА }\end{array}$ & $\begin{array}{c}\text { Рыночная } \\
\text { ценность НМА }\end{array}$ & Разница \\
\hline 1 & РАО ЕЭС & 168465,38 & 41031,362 & 127434,02 \\
\hline 2 & Ростелеком & 37226,66 & 5789,22 & 31437,44 \\
\hline 3 & НТМК & 39029,87 & 17262,05 & 21767,82 \\
\hline 4 & Мегионнефтегаз & 18155,10 & 6424,72 & 11730,38 \\
\hline 5 & Аэрофлот & 17846,68 & 6439,28 & 11407,40 \\
\hline & Северо-Западный & 12527,66 & 1188,00 & 11339,66 \\
6 & Телеком & 846,47 & 179,42 & 10706,74 \\
\hline 7 & Тулэнерго & 82,92 & 26,78 & 7566,28 \\
\hline 8 & Дальсвязь & 17412,92 & 11207,97 & 6204,95 \\
\hline 9 & Автоваз & 909,12 & 281,49 & 5100,24 \\
\hline 10 & Уфимское МПО & 16885,30 & 12824,57 & 4060,73 \\
\hline 11 & Челябэнерго & 6003,73 & 2743,66 & 3260,07 \\
\hline 12 & Оренбургнефть & 4180,67 & 1509,02 & 2671,65 \\
\hline 13 & ВолгаТелеком & 3334,77 & 1205,69 & 2129,08 \\
\hline 14 & Дагэнерго & 14219,30 & 12520,34 & 1698,96 \\
\hline 15 & Башкирэнерго & 10889,10 & 9969,88 & 919,22 \\
\hline 16 & Северсталь & 1294,39 & 659,02 & 635,37 \\
\hline 17 & Архэнерго & 1700,44 & 1176,18 & 524,26 \\
\hline 18 & Уфанефтехим & & & \\
\hline
\end{tabular}

Данные, представленные в табл. 7 и 8, говорят о том, что большинство компаний из анализируемой выборки недооценены с точки зрения оценки их нематериальных активов рынком, при этом в большинстве своем это компании трех отраслей: энергетической, добывающей и отрасли связи. Остальные компании из общей выборки не вошли ни в одну из представленных групп в силу того, что рыночная стоимость их НМА равна или ниже нуля. Деятельность данных компаний можно охарактеризовать следующим образом: управление нематериальными активами в них происходит неэффективно, а соответственно, и генерируемая доходность ниже среднеотраслевой.

В то же время у ряда компаний рыночная ценность нематериальных активов ниже, чем теоретическая (табл. 9), что говорит о недооценке данного вида активов рынком.

Таблица 9

Превышение теоретической ценности НМА над рыночной (млн руб.) в 2006 г.

\begin{tabular}{|l|l|c|c|c|}
\hline № & \multicolumn{1}{|c|}{ Компания } & $\begin{array}{c}\text { Теоретическая } \\
\text { ценность НМА }\end{array}$ & $\begin{array}{c}\text { Рыночная } \\
\text { ценность НМА }\end{array}$ & Разница \\
\hline 1 & Ростелеком & 40252,70 & 5789,22 & 34463,48 \\
\hline 2 & НТМК & 40965,96 & 17262,05 & 23703,91 \\
\hline 3 & Аэрофлот & 22902,47 & 6439,28 & 16463,19 \\
\hline 4 & Мегионнефтегаз & 22653,34 & 6424,72 & 16228,62 \\
\hline 5 & Оренбургнефть & 12783,06 & 2743,66 & 10039,40 \\
\hline 6 & ВолгаТелеком & 9971,29 & 1509,02 & 8462,27 \\
\hline 7 & Башкирэнерго & 20899,25 & 12520,34 & 8378,91 \\
\hline 8 & Автоваз & 18672,43 & 11207,97 & 7464,46 \\
\hline 9 & Уфимское МПО & 7111,03 & 281,49 & 6829,54 \\
\hline 10 & Архэнерго & 7153,34 & 659,02 & 6494,32 \\
\hline 11 & Уфанефтехим & 7599,08 & 1176,18 & 6422,90 \\
\hline
\end{tabular}




\begin{tabular}{|c|l|c|c|c|}
\hline 12 & Тулэнерго & 6554,48 & 179,42 & 6375,06 \\
\hline 13 & Дальсвязь & 6244,17 & 26,78 & 6217,39 \\
\hline 14 & Казаньоргсинтез & 5451,36 & 0 & 5451,36 \\
\hline 15 & РИТЭК & 4869,78 & 0 & 4869,78 \\
\hline 16 & Дагэнерго & 5486,74 & 1205,69 & 4281,05 \\
\hline 17 & Московская ГТС & 6854,37 & 3422,72 & 3431,65 \\
\hline 18 & Комиэнерго & 2833,53 & 0 & 2833,53 \\
\hline & Северо-Западный & & & \\
19 & Телеком & 3758,19 & 1188,00 & 2570,19 \\
\hline 20 & ГАЗ & 7830,43 & 5381,73 & 2448,70 \\
\hline 21 & Челябэнерго & 14985,47 & 12824,57 & 2160,90 \\
\hline 22 & Сибирьтелеком & 1858,86 & 0 & 1858,86 \\
\hline
\end{tabular}

Если проанализировать рост фундаментальной ценности нематериальных активов относительно базового года, то можно ранжировать компании по данному принципу следующим образом (табл. 10).

Таблица 10

Темп роста фундаментальной ценности НМА (первая «десятка» компаний)

\begin{tabular}{|l|l|l|l|l|l|l|}
\hline № & \multicolumn{1}{|c|}{ Компания } & $\begin{array}{c}\mathbf{2 0 0 2 /} \\
\mathbf{2 0 0 1}\end{array}$ & \multicolumn{1}{|c|}{ Компания } & $\begin{array}{c}\mathbf{2 0 0 3 /} \\
\mathbf{2 0 0 1}\end{array}$ & \multicolumn{1}{|c|}{ Компания } & $\begin{array}{c}\mathbf{2 0 0 4 /} \\
\mathbf{2 0 0 1}\end{array}$ \\
\hline 1 & Дагэнерго & 9,22 & РИТЭК & 24,55 & РИТЭК & 33,73 \\
\hline 2 & ВолгаТелеком & 6,62 & Дагэнерго & 17,89 & Дагэнерго & 17,70 \\
\hline 3 & РАО ЕЭС & 4,28 & Ростелеком & 7,46 & Дальсвязь & 16,48 \\
\hline 4 & Башнефть & 4,09 & ВолгаТелеком & 4,06 & Ростелеком & 6,82 \\
\hline 5 & РИТЭК & 2,82 & Уралсвязьинформ & 3,89 & ВолгаТелеком & 4,69 \\
\hline 6 & Аэрофлот & 2,27 & Башнефть & 3,30 & Аэрофлот & 4,29 \\
\hline 7 & Челябэнерго & 1,93 & НТМК & 2,86 & Комиэнерго & 3,66 \\
\hline 8 & Ростелеком & 1,08 & Аэрофлот & 2,73 & НТМК & 3,23 \\
\hline 9 & Казаньоргсинтез & 1,03 & РАО ЕЭС & 2,62 & Уралкалий & 3,10 \\
\hline 10 & Сургутнефтегаз & 0,94 & Челябэнерго & 1,96 & РАО ЕЭС & 2,05 \\
\hline
\end{tabular}

(продолжение)

\begin{tabular}{|l|l|l|l|l|}
\hline № & \multicolumn{1}{|c|}{ Компания } & $\mathbf{2 0 0 5 / 2 0 0 1}$ & \multicolumn{1}{|c|}{ Компания } & $\mathbf{2 0 0 6 / 2 0 0 1}$ \\
\hline 11 & РИТЭК & 21,54 & Сибнефть & 27,57 \\
\hline 12 & Дагэнерго & 17,83 & Уфимское МПО & 23,63 \\
\hline 13 & Уфанефтехим & 10,56 & РИТЭК & 13,73 \\
\hline 14 & Ростелеком & 8,045 & Уфанефтехим & 13,02 \\
\hline & & & $\begin{array}{l}\text { Роснефть- } \\
\text { Пурнефтегаз }\end{array}$ & 11,13 \\
\hline 15 & НТМК & 6,99 & Башкирэнерго & 10,045 \\
\hline 16 & ВолгаТелеком & 6,13 & Московская ГТС & 3,59 \\
\hline 17 & Дальсвязь & 5,07 & Аэрофлот & 3,58 \\
\hline 18 & Мегионнефтегаз & 4,10 & Архэнерго & 3,41 \\
\hline 19 & Аэрофлот & 3,67 & Оренбургнефть & 3,01 \\
\hline 20 & Тулэнерго & 2,79 & \multicolumn{2}{|l}{} \\
\hline
\end{tabular}

Нематериальные активы играют значительную роль в создании ценности компании, а представленные в работе результаты говорят о положительной фундаментальной ценности нематериальных активов многих российских компаний из выборки. Известно, что рост фундаментальной ценности НМА компаний приводит к росту ценности для собственников. 
Это же характерно и для российских компаний. Как видно из данных табл. 9, максимальный темп роста фундаментальной ценности нематериальных активов наблюдается у компаний трех отраслей: добывающей, энергетической и отрасли связи, что говорит о том, что именно для этих отраслей характерен значительный рост ценности для собственников.

Если проанализировать рис. 3, то можно еще раз убедиться в том, что именно в энергетической отрасли наблюдается максимальный рост фундаментальной ценности нематериальных активов, особенно в период до 2004 г. По графику видно, что в трех отраслях из пяти - в добывающей промышленности, в энергетике и металлургии - в 2005 г. произошло значительное снижение фундаментальной ценности НМА. Кроме того, можно отметить то, что лишь для отрасли связи характерна минимальная волатильность фундаментальной ценности НМА за весь период наблюдения с 2001-го по 2006 г.

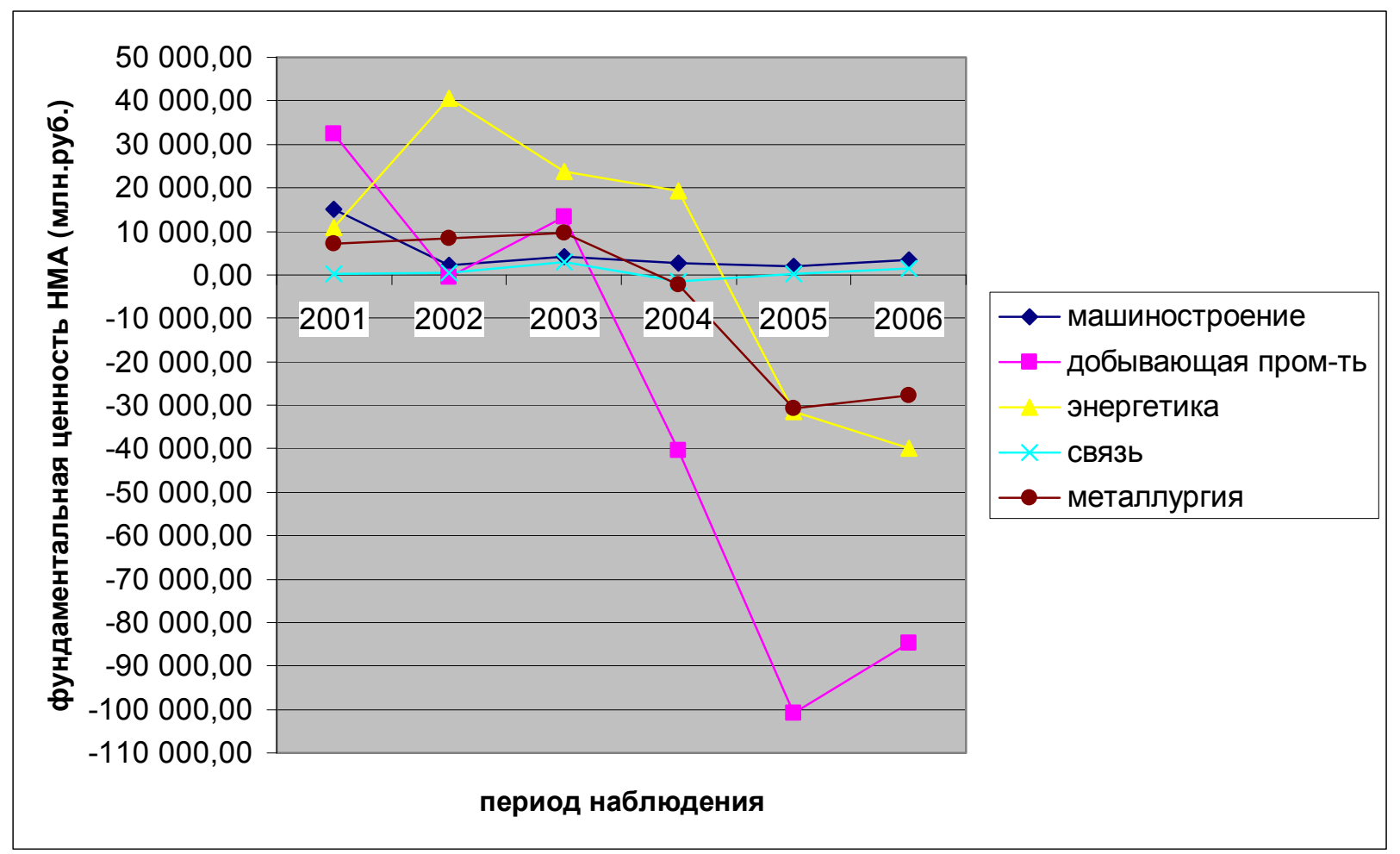

Рис. 3. Изменение фундаментальной ценности НМА по отраслям

Ниже показаны результаты, в которых представлен относительный рост рыночной ценности нематериальных активов. Как видно из табл. 11, максимальный рост рыночной ценности также наблюдается в компаниях лидирующих отраслей: добывающей, энергетической и отрасли связи.

Таблица 11

Темп роста рыночной стоимости НМА (первая «десятка» компаний)

\begin{tabular}{|c|c|c|c|c|c|c|}
\hline № & Компания & $\begin{array}{l}2002 / \\
2001\end{array}$ & Компания & $\begin{array}{l}2003 / \\
2001\end{array}$ & Компания & $\begin{array}{l}2004 / \\
2001\end{array}$ \\
\hline 1 & Мегионнефтегаз & 76,20 & Уралсвязьинформ & 57,52 & Уралсвязьинформ & 95,15 \\
\hline 2 & Уралсвязьинформ & 71,99 & Уфимское МПО & 46,29 & Мегионнефтегаз & 32,19 \\
\hline 3 & Ростелеком & 40,60 & Мегионнефтегаз & 38,50 & Уфимское МПО & 26,66 \\
\hline 4 & Лукойл & 23,16 & $\begin{array}{l}\text { ВСМПО- } \\
\text { АВИСМА }\end{array}$ & 22,19 & Ростелеком & 20,22 \\
\hline 5 & $\begin{array}{l}\text { ВСМПО- } \\
\text { АВИСМА }\end{array}$ & 22,83 & Сибнефть & 8,72 & $\begin{array}{l}\text { ВСМПО- } \\
\text { АВИСМА }\end{array}$ & 13,29 \\
\hline 6 & Сибнефть & 12,54 & PAO ЕЭС & 4,55 & Сибнефть & 9,84 \\
\hline 7 & Уралкалий & 12,38 & Аэрофлот & 4,02 & Кузбасэнерго & 2,69 \\
\hline
\end{tabular}




\begin{tabular}{|l|l|l|l|l|l|l|}
\hline 8 & Казаньоргсинте & 8,89 & Лукойл & 2,86 & Оренбургнефть & 1,49 \\
\hline 9 & Аэрофлот & 3,77 & ВолгаТелеком & 1,11 & Лукойл & 1,43 \\
\hline 10 & Татнефть & 3,21 & КАМАЗ & 0,95 & Северсталь & 1,30 \\
\hline
\end{tabular}

\begin{tabular}{|c|c|c|c|c|}
\hline № & Компания & $2005 / 2001$ & Компания & $2006 / 2001$ \\
\hline 11 & РАО ЕЭС & 7,44 & Сургутнефтегаз & 14,58 \\
\hline 12 & КамА3 & 4,72 & ВолгаТелеком & 6,16 \\
\hline 13 & Сургутнефтегаз & 4,33 & Ростелеком & 2,99 \\
\hline 14 & Кузбасэнерго & 2,75 & Кузбасэнерго & 1,56 \\
\hline 15 & $\begin{array}{l}\text { Уфимское } \\
\text { МПО }\end{array}$ & 1,51 & Северсталь & 0,84 \\
\hline 16 & Оренбургнефть & 0,88 & ГАЗ & 0,81 \\
\hline 17 & РИТЭК & 0,76 & $\begin{array}{l}\text { Уфимское } \\
\text { МПО }\end{array}$ & 0,78 \\
\hline 18 & ГА3 & 0,63 & Оренбургнефть & 0,69 \\
\hline 19 & Северсталь & 0,12 & Аэрофлот & 0,31 \\
\hline 20 & Автоваз & 0,01 & Мосэнерго & 0,21 \\
\hline
\end{tabular}

В целом в компаниях анализируемой выборки доля фундаментальной ценности НМА в фундаментальной ценности всех активов компании достаточно мала, о чем говорят результаты, приведенные в табл. 12 .

Таблица 12 Доля фундаментальной ценности НМА в фундаментальной ценности всех активов (первая «десятка» компаний) (в \%)

\begin{tabular}{|c|c|c|c|c|c|c|}
\hline № & Компания & 2001 & Компания & 2002 & Компания & 2003 \\
\hline 1 & $\begin{array}{l}\text { Норильский } \\
\text { никель }\end{array}$ & 9,26 & Ленэнерго & 7,74 & $\begin{array}{l}\text { Норильский } \\
\text { никель }\end{array}$ & 2,70 \\
\hline 2 & Архэнерго & 8,76 & Нор.никель & 7,83 & Иркутскэнерго & 1,95 \\
\hline 3 & Ленэнерго & 3,70 & Кузбасэнерго & 5,76 & Архэнерго & 1,63 \\
\hline 4 & Иркутскэнерго & 3,31 & Мегионнефтегаз & 3,55 & Самарэнерго & 1,48 \\
\hline 5 & Кузбасэнерго & 3,00 & Мосэнерго & 2,84 & Дальсвязь & 1,23 \\
\hline 6 & Оренбургнефть & 2,15 & Архэнерго & 2,43 & $\begin{array}{l}\text { Московская } \\
\text { ГТС }\end{array}$ & 1,23 \\
\hline 7 & Мегионнефтегаз & 1,55 & Иркутскэнерго & 2,39 & ЮТК & 0,83 \\
\hline 8 & Московская ГТС & 1,46 & ЧТПЗ & 1,82 & Мосэнерго & 0,80 \\
\hline 9 & ГА3 & 0,97 & Самарэнерго & 1,11 & Дагэнерго & 0,66 \\
\hline 10 & $\begin{array}{l}\text { Северо-Западный } \\
\text { Телеком }\end{array}$ & 0,60 & PAO ЕЭС & 0,70 & Ростелеком & 0,60 \\
\hline
\end{tabular}

(продолжение)

\begin{tabular}{|l|l|l|l|l|l|l|}
\hline № & Компания & 2004 & Компания & 2005 & Компания & 2006 \\
\hline 11 & Кузбасэнерго & 7,50 & Кузбасэнерго & 12,97 & Челябэнерго & 7,87 \\
\hline 12 & ЦентрТелеком & 2,59 & Сургутнефтегаз & 4,05 & Кузбасэнерго & 3,92 \\
\hline 13 & $\begin{array}{l}\text { Норильский } \\
\text { никель }\end{array}$ & 2,33 & ЦентрТелеком & 2,51 & Комиэнерго & 3,14 \\
\hline 14 & Уралсвязьинформ & 1,74 & Иркутскэнерго & 2,08 & Тулэнерго & 3,05 \\
\hline \multirow{2}{*}{15} & $\begin{array}{l}\text { Роснефть- } \\
\text { Пурнефтегаз }\end{array}$ & 1,73 & Ленэнерго & 1,73 & Иркутскэнерго & 2,67 \\
\hline
\end{tabular}




\begin{tabular}{|l|l|l|l|l|l|l|}
\hline 16 & ЮТК & 1,07 & Комиэнерго & 1,72 & Мосэнерго & 2,34 \\
\hline 17 & Сибирьтелеком & 0,64 & Мосэнерго & 1,46 & Ленэнерго & 2,05 \\
\hline 18 & Дагэнерго & 0,63 & Самарэнерго & 1,46 & Сургутнефтегаз & 1,95 \\
\hline 19 & Сургутнефтегаз & 0,61 & Уралсвязьинформ & 1,32 & РИТЭК & 1,02 \\
\hline 20 & Ростелеком & 0,61 & $\begin{array}{l}\text { Роснефть- } \\
\text { Пурнефтегаз }\end{array}$ & 1,15 & КАМА3 & 0,85 \\
\hline
\end{tabular}

Как видно из данных табл. 12, максимальная доля фундаментальной ценности НМА в общей фундаментальной ценности всех активов в целом по «десятке» лидеров присуща компаниям все тех же трех отраслей: добывающей, энергетической и отрасли связи. Фактически это еще раз подтверждает вывод, сделанный выше, о том, что именно в упомянутых отраслях наблюдается максимальный рост ценности для собственников.

Данный аспект еще раз подтверждает мысль, высказанную в работе Лев и Даум [Lev, Daum, 2004, с. 7], о том, что «сами по себе нематериальные активы не создают ценность компании, для этого необходима эффективная система поддержки». Другими словами, использование нематериальных активов значительно зависит от их развития и качественного управления ими, что позволяет извлекать материальную выгоду из нематериальных ресурсов.

\section{Выводы}

В работе представлен метод расчета трех видов ценностей нематериальных активов: рыночной, фундаментальной и теоретической, что позволяет провести анализ того, насколько справедливо оценен данный вид активов рынком для каждой компании из выборки. Проведенное исследование говорит о том, что на сегодняшний день большинство российских компаний из анализируемой выборки недооценены с точки зрения ценности нематериальных активов как при сравнении рыночной ценности НМА с фундаментальной, так и с теоретической ценностью. Для данного вида активов такой результат является ожидаемым с той точки зрения, что нематериальные активы по своей природе очень сложно поддаются измерению, а значит, «рынку» особенно сложно объективно оценить их ценность. Из шести анализируемых в работе отраслей - машиностроения, добывающей отрасли, энергетики, отрасли связи, химической и металлургии - в наибольшей степени недооценены нематериальные активы в компаниях добывающей отрасли, энергетики и связи, т.е. в тех отраслях, где по результатам, полученным Волковым и Гараниной [Волков, Гаранина, 2007], нематериальные активы играют наибольшую роль в создании ценности компании. Полученные результаты также подтверждают тот факт, что фундаментальная ценность нематериальных активов у ряда компаний отрицательна, что подтверждает выдвинутые в исследовании предположения.

При управлении компанией важно помнить о том, что существуют и другие положительные аспекты управления НМА, кроме создания ценности для собственников, а именно:

- при проведении сделок слияния и поглощения стоимость поглощаемой компании, у которой ценность НМА является значительной, будет значительно выше, чем у той, которая не оценивает свои НМА;

- компания, оценивающая и отражающая свои НМА, может рассчитывать на более низкую ставку по привлекаемым кредитам, так как уровень доверия к таким компаниям выше;

- увеличение свободных денежных потоков, создаваемых НMA, обеспечивает поддержание ликвидности операций. Способность компании создавать объем ликвидных ресурсов, достаточный для решения стратегических задач, повышает ее маневренность в быстро изменяющейся деловой среде. Заинтересованные стороны получают возможность получать доход в наиболее удобной форме, что стимулирует 
приток ресурсов в компанию;

- пока компания своевременно и полно проводит оценку своих НМА и отражает ее в отчетности, данная информация помогает инвесторам более точно прогнозировать ее будущие доходы, что способствует повышению стабильности цен на акции. Это в свою очередь снижает риски, связанные с компанией, что и приводит к снижению стоимости капитала.

Нематериальные активы должны быть объектом пристального внимания менеджеров компании, о чем говорит тот факт, что благодаря наличию и эффективному использованию HМА возможно создавать ценность компании путем увеличения денежных потоков как в прогнозном, так и в постпрогнозном периоде, ускорения денежных потоков и снижения ставки по привлеченным средствам.

Процедуры управления ценностью образуют систему стратегических и оперативных решений, в которой все устремления и действия направлены на максимизацию ценности компании. Базой принятия решений по управлению ценностью служит анализ ключевых факторов, влияющих на ее создание. При этом в экономике знаний ведущую роль среди ключевых факторов создания ценности играют нематериальные активы.

\section{Список литературы}

1. Бухвалов А.В., Волков Д.Л. Исследование зависимости между фундаментальной ценностью и рыночной капитализацией российских компаний // Вестник С.Петербургского ун-та. Сер. Менеджмент. - 2005а. — № 1. - С. 26-44.

2. Бухвалов А.В., Волков Д.Л. Фундаментальная ценность собственного капитала: использование в управлении компанией // Научные доклады НИИ Менеджмента СПбГУ. 2005б. - № 1.

3. Волков Д.Л. Модели оценки фундаментальной стоимости собственного капитала компании: проблема совместимости // Вестник С.-Петербургского ун-та. Сер. Менеджмент. - 2004a. - № 3. - С. 3-36.

4. Волков Д.Л. Управление стоимостью компаний и проблема выбора адекватной модели оценки // Вестник С.-Петербургского ун-та. Сер. Менеджмент. — 2004б. — № 4. - С. 79-98.

5. Волков Д.Л. Показатели результатов деятельности: использование в управлении стоимостью компании // Российский журнал менеджмента. - 2005a. - № 3 (2). - С. $3-42$.

6. Волков Д.Л. Управление ценностью: показатели и модели оценки // Российский журнал менеджмента. — 2005б. — № 3 (4). — С. 67-76.

7. Волков Д.Л. Теория ценностно-ориентированного менеджмента: финансовый и бухгалтерский аспекты. СПб.: Издат.дом С.-Петерб. ун-та, 2006.

8. Волков Д.Л., Березинец И.В. Управление ценностью: анализ основанных на бухгалтерских показателях моделей оценки // Научные доклады НИИ Менеджмента СПбГУ. - 2006а. - № 3 (R). - 2006а.

9. Волков Д.Л., Березинец И.В. Модели взаимосвязи между фундаментальными и рыночными оценками собственного капитала. Корпоративное управление и оценивание компаний: актуальные проблемы и программа исследований. СПб.: Факультет менеджмента СПбГУ, 2006б.

10. Волков Д.Л., Гаранина Т.А. Нематериальные активы: проблемы состава и оценивания // Вестник С.-Петерб. ун-та. Серия Менеджмент. - 2007. - Вып. 1. - С. 82-105.

11. Лев Б. Нематериальные активы: управление, измерение, отчетность. М.: КвинтоКонсалтинг, 2003.

12. О порядке оценки стоимости чистых активов акционерных обществ. Приказ Министерства финансов Российской Федерации и Федеральной комиссии по рынку ценных бумаг от 5 августа 1996 г. №71/149. 
13. Aboody, D., Baruch, L. (2001), The Productivity of Chemical Research and Development. Working Paper. - New York University: Stern School of Business.

14. Ahonen, G. (2000), Generative and commercially exploitable intangible assets, Classification of Intangibles. - Groupe HEC: Jouy-en-Josas, p. 206-213.

15. Copeland, T., Koller, T., Murrin, J. (1995), Valuation: Measuring and Managing the Value of Companies, 2nd ed. - N.-Y.: John Wiley \& Sons.

16. Eustace C. (ed.). The PRISM Report. (2003), Research Findings and Policy Recommendations. - EU (IST).

17. Freeman, Ch., Soete, L. (1997), The Economics of Industrial Innovation, 3d ed. - MIT Press.

18. Grant, R.M. (1991), The resource-based theory of competitive advantage: Implications for strategy formulation, California Management Review 33 (3): 114-135.

19. Griliches, Z. (1995), R\&D and Productivity: Econometric Results and Measurement Issues, Handbook of the Economics of Innovation and Technological Change. - UK: Blackwell.

20. Hall, B. (1993), Industrial Research during the 1980s: Did the Rate of Return Fall? Microeconomics 3: 289-393.

21. Higgins, R. (1995). Analysis for Financial Management. - Chicago: Irwin.

22. Kaplan, R.S., Norton D.P. (2004), Strategy maps - converting intangible assets into tangible outcomes. - Harvard Business School Press: Boston, MA.

23. Knight, J. (1998), Value-based Management: Developing a Systematic Approach to Creating Shareholder Value. - N.Y.: McGraw-Hill.

24. Lev, B., Daum, J.H. (2004), The Dominance of Intangibles Assets: Consequences for Enterprise Management and Corporate Reporting, Measuring Business Excellence, 8 (1): 617.

25. Lev, B., Feng, G. (2001), Intangible assets: measurement, drivers, usefulness. - New York University, New York, NY.

26. Nahapiet, J., Ghoshal, S. (1998), Social capital, intellectual capital, and the organizational advantage, Academy of Management Review 23: 242-266.

27. Teece, D.J. (2000), Managing Intellectual Capital. - Oxford University Press: Oxford. 